Marcin Choczyński

Uniwersytet Kardynała Stefana Wyszyńskiego w Warszawie

\title{
OGÓLNOPOLSKA KONFERENCJA NAUKOWA GEORG SIMMEL. W SETNĄ ROCZNICĘ ŚMIERCI MISTRZA SOCJOLOGII, UKSW 2018
}

26 września 2018 r. na Uniwersytecie Kardynała Stefana Wyszyńskiego w Warszawie (UKSW) odbyła się ogólnopolska konferencja naukowa Georg Simmel. W setna rocznice śmierci mistrza socjologii poświęcona recepcji wielkiego niemieckiego socjologa we współczesnej socjologii. Organizatorzy wydarzenia - Instytut Socjologii UKSW przy współpracy z Polskim Towarzystwem Socjologicznym oraz Narodowym Centrum Kultury - postawili sobie za cel przybliżenie sylwetki naukowej oraz dorobku klasyka myśli społecznej wciąż inspirującego do poszukiwania coraz to nowych obszarów analizy naukowej.

Konferencję otworzył Krzysztof Wielecki, dyrektor Instytutu Socjologii UKSW, który nakreślił jej ramy i wymiar symboliczny, a także zaakcentował znaczenie dorobku Simmla i jego niewyczerpany wpływ na współczesne nauki społeczne, w tym nie tylko socjologię, lecz także filozofię, kulturoznawstwo czy ekonomię. Wielość dziedzin poznania, które korzystają z dziedzictwa Simmlowskiego, ukazuje wartość naukowych analiz poczynionych przez tego socjologa. Prelegenci, reprezentujący główne polskie ośrodki socjologiczne, przedstawili trzynaście referatów. Dywersyfikacja pochodzenia uczestników pozwoliła na zaprezentowanie zróżnicowanych punktów widzenia i panoramiczne ujęcie recepcji myśli simmlowskiej, co stanowi o wartości poznawczej tego naukowego wydarzenia.

W sesji plenarnej, której przewodniczył Tomasz M. Korczyński (UKSW), wygłoszono pięć referatów.

Andrzej Waśkiewicz z Uniwersytetu Warszawskiego (UW) w wystąpieniu Poza wymiana towarowa i redystrybucja. Wktad Georga Simmla w rozumienie utopii antykapitalistycznych pochylił się nad ekonomizacyjnymi wątkami w twórczości Simmla, a szczególnie wybranymi zagadnieniami z pracy Filozofia pieniądza. Scharakteryzował trzy nurty twórczości utopistycznej, w której główną rolę odgrywają rzeczy, w kontekście harmonii i użyteczności w życiu ludzi, także specyficznej dogodności dla jednostek. Ukazał mechanizmy gospodarcze i interwencjonizm państwa w wymiarze: reglamentacji zasobów (rzeczy) jednostek, odtowarowienia oraz odwartościowania. W nawiązaniu do odtowarowienia prelegent zaakcentował kwestię nadania rzeczom rangi odwzajemnionych darów (przy czym zbliżył się do antropologicznego uchwycenia wymiany społecznej), natomiast odwartościowanie zostało opisane poprzez swobodny i bezpłatny w dużej mierze dostęp do rzeczy w dobie postępu technologicznego oraz globalnej gospodarki dobrobytu. Ważną kwestią w podjętych rozważaniach była także uniformizacja działań związanych z konsumpcją rzeczy i dóbr, jak również odniesienie do kondycji współczesnego kapitalizmu, który został podzielony na trzy epoki - przedkapitalistyczną, „akapitalistyczną” i postkapitalistyczną. Wystąpienie to było propozycją twórczego ujęcia i zarazem rozwinięcia wątków simmlowskich w nawiązaniu do przemian współczesnego kapitalizmu.

Krzysztof Wielecki (UKSW) i Monika Bukowska (UKSW) przedstawili Problem subiektywizmu teorii Georga Simmla. Autorzy odnieśli się do specyfiki teorii Simmlowskiej, umieszczając ją w strukturze teorii socjologicznych na ważnym miejscu z punktu widzenia polisemiczności podejmowanych wątków. Zwrócono uwagę na rolę subiektywizmu i jego determinanty w zachowaniu jednostek, w tym na wybory ekonomiczne, pociągające za sobą określone skutki, chociażby w wymiarze materialnym i statusowym. Subiektywizm przedstawiony został także z perspektywy poznania - sam Simmel dał mu wyraz w dziele pt. Obcy - oraz w powiązaniu ze specyficznym traktowaniem własnych, indywidualnych przejawów odczuwania stanów rzeczy, również stosunku do otaczającego środowiska i społeczeństwa.

W wystąpieniu Simmel jako wieszcz postmodernizmu? Aporie i transgresje Simmlowskiej socjologii Grażyna Romańczuk-Woroniecka (UW) zaproponowała odczytanie twórczości Simmla w kontekście współczesnych uwarunkowań ponowoczesnej syntezy kulturowej, w której widoczne są zarówno nawiązania do dzieł 
uznawanych za klasyczne, jak i ich twórcze trawestacje. Autorka zaakcentowała prognostyczną rolę Simmla jako myśliciela niejako zapowiadającego przyszłe dekompozycje modeli kultury, ze ścisłymi zmianami jej istoty oraz znaczenia.

Marek Czyżewski z Uniwersytetu Łódzkiego (UŁ) w referacie „Tragedia kultury”. Simmlowskie spojrzenie na kulturę wspótczesna przedstawił kulturę w optyce simmlowskiej, uwypuklając jej istotne cechy. Zwrócił uwagę na przeobrażenia w tej sferze, również na zasadniczy problem dekompozycji wartości kulturowych we współczesności, które podporządkowane są prądom postmodernistycznym.

W pierwszej z dwóch sesji panelowych, której przewodniczył Tomasz M. Korczyński, wygłoszono cztery referaty.

Beata Hoffmann (UW) w wystąpieniu Georg Simmel i flakonik perfum prześledziła zmiany w postrzeganiu zmysłu powonienia, jakie zaszły na przestrzeni lat, i uwypukliła rolę Simmlowskiej socjologii, w której problematyka ta po raz pierwszy zyskała duże znaczenie. Prelegentka zwróciła uwagę na proces socjalizacji zapachowej, podczas której zachodzą procesy stratyfikacyjne. Z jednej strony zapach ciała, indywidualny dla każdego człowieka, zbliża, jak nic innego, do świata naturalnego (derywat biologiczny), z drugiej jednak strony to kultura nadała znaczenia powonieniu i określiła na swój sposób zapachowe standardy czy wzorce (fenomen kulturowy). To także integralny składnik tożsamości człowieka, ukazuje jego cechy wrodzone, takie jak płeć lub wiek, ale również styl życia i środowisko, w jakim przebywa. Ponadto odgrywa ważną rolę w praktykach rytualnych, medycznych czy obyczajowych, przekładając się tym samym na określenie relacji międzyludzkich pod postacią kodu zapachowego, silnie nacechowanego sprecyzowanymi charakterystykami.

„Prymitywny i nikczemny” akt jedzenia w perspektywie uspoteczniającej i estetyzujacej życie codzienne jednostki i wspólnoty analizowała Mariola Bieńko (UW), odnosząc się do estetyki posiłku i kultury jedzenia w wybranych perspektywach badawczych oraz opierając na analizie pogłębionych wywiadów indywidualnych przeprowadzonych z mieszkańcami wybranych miast w latach 2012-2014. Podobnie jak zapach, jedzenie także nie od razu stało się przedmiotem rozważań nauk społecznych, a w szczególności socjologii. W optyce simmlowskiej jedzenie jest jedną z form uspołecznienia, a formy zbiorowej konsumpcji pozwalają na zmniejszenie dystansu i zacieśnianie kontaktu. Według referentki praktyki i preferencje kulinarne nadają relacjom społecznym bardziej doniosłe znaczenie i odpowiadają w dużym stopniu za estetyzację znajomości. Zbliżona wrażliwość i podobne gusta kulinarne tworzą również więzi wspólnotowe, mają zatem moc sprawczą w obszarze kreowania relacji społecznych. Badaczka odniosła się ponadto do znaczenia estetycznego waloru konsumowania opartego raczej na perspektywie zbiorowej niż indywidualnej.

Rolę gromadzenia zasobów w wyrażaniu tożsamości przez aktorów społecznych omówiła Renata Dopierała (UŁ) w referacie „Posiadanie jako sfera i wyraz Ja”- dobrowolna prostota w kontekście pism Georga Simmla. Prelegentka przedstawiła zaobserwowane w Simmlowskiej socjologii: orientację na człowieka, samookreślenie, rozwój osobowy i świadomość ekologiczną. Niezwykle ważne w tym kontekście jest wskazanie roli pieniądza w ustanawianiu relacji międzyludzkich. Badaczka odniosła się również do fragmentów Filozofii pieniądza, w której zaakcentowano sens posiadania, ideę rozporządzania (gospodarowania) rzeczami, specyficznego statusu rzeczy w aspekcie ich materialnego charakteru, kreśląc przy tym zasadniczy sens wymiany w odwołaniu zarówno do sfery ekonomicznej, jak i społecznej. Wszystkie te wymiary zostały zestawione z ideami głoszonymi przez ruch dobrowolnej prostoty, takimi jak wdzięczność i umiar konsumpcyjny, z problematyką rozrzutności i marnotrawstwa.

Wystąpienie Dariusza Brzezińskiego (Polska Akademia Nauk) Teoria kultury Georga Simmla w perspektywie wspótczesnej humanistyki i myśli spotecznej miało cechy pewnej syntezy. Referent odniósł się do szeroko pojmowanej refleksji nad kulturą i jej znaczenia w dorobku Simmla. Przywołał obecne ujmowanie kultury, zarówno w postaci „systemowej”, jak i „repertuarowej”. Klasyczne ustalenia Simmlowskie na temat kultury zostały zestawione z poglądami takich uczonych, jak m.in. Ann Swidler, Margaret S. Archer, William Sewell jr, Wendy Griswold, Zygmunt Bauman oraz Stephen Vaisey. Dużo uwagi poświęcono zagadnieniu podmiotowości i sprawstwa w kulturze - działaniom inicjującym oraz korygującym sam rdzeń kultury.

W równolegle odbywającej się drugiej sesji panelowej, której przewodniczył Marcin Choczyński (UKSW), wygłoszono pięć referatów. 
Paweł Prüfer (Akademia im. Jakuba z Paradyża w Gorzowie Wielkopolskim) w wystąpieniu pt. „Stare” $i$ "nowe" Georga Simmla, linearne i cykliczne Pawta Prüfera trajektorie interpretacyjne jednostki i spoteczeństwa - zbieżność i różnorodność w konfrontacji odniósł się do problematyki logiki rozwoju społecznego, zaprezentowanej przez Simmla, a ujmowanej w kategoriach procesu i opartej na stosunku zarówno do tradycji, jak i przyszłości. W tym kontekście nakreślił autorską koncepcję, nazwaną „maturacjonizmem linearno-cyklicznym”, oraz przybliżył jej założenia metodologiczne i epistemologiczne, odwołując się do klasycznych definicji Simmla, takich jak np. logika relacyjna, a także włoskiej myśli socjologicznej, reprezentowanej przez Franca Ferrarottiego czy Pierpaola Donatiego.

Zasługi niemieckiego klasyka dla rozwoju socjologii historycznej, subdyscypliny odwołującej się do analizy przeszłych zjawisk społecznych w optyce historiozofii - filozofii historii (dziejów), przedstawił Borys Cymbrowski (Uniwersytet Opolski). W referacie Georg Simmel jako socjolog historyczny. Na marginesie "Problemu czasu historycznego" odniósł się do mniej znanej pracy pioniera formalizmu socjologicznego, traktując ją jako punkt wyjścia do kreślenia wizji dotyczących przeszłości, jej wpływu na współczesność oraz znaczenia konkretnych faktów historycznych. Ważnym rysem wystąpienia była również próba panoramicznej interpretacji historii społecznej oraz ukazanie istoty czasu i jego znaczenia dla praktyk społecznych.

W strone kultury materialnej. Spoteczeństwo polskie w ujęciu perspektywy socjologii gospodarczej to próba przedstawienia kondycji współczesnego społeczeństwa polskiego w odniesieniu do takich Simmlowskich kategorii poznawczych, jak m.in. wzrost kultury materialnej, regres kultury indywidualnej, tendencje do separacji kultury subiektywnej oraz obiektywnej, a także rola pieniądza. Jordan Klimek (Uniwersytet Szczeciński) uwypuklił wyznaczniki współczesnego stylu życia, zwłaszcza ukierunkowanie na wartości materialne. Zarysował również panoramiczne przeobrażenia w strukturze społecznej, a w szczególności istotną modyfikację interakcji poprzez osłabienie więzi społecznych, oraz wskazał na zjawisko zindywidualizowania społeczeństwa jako kierunek realizacji własnych aspiracji, ambicji, prowadzących do osiągania celów jednostkowych.

W wystąpieniu zatytułowanym Wielowymiarowa analiza komunikacji matżeńskiej-jako próba tączenia treści i formy narracji Izabeli Holak (UŁ) uwypuklone zostały trwałe formy stosunków międzyludzkich, niezależne od kontekstów przeszłości i indywidualnych uwarunkowań, które opisywał w swojej twórczości Simmel. Zaprezentowano formy uspołecznienia, rozumiane jako permanentne oddziaływanie jednostek nawzajem, których komunikacja oparta jest na transakcji oraz wymianie w dążeniu do własnych celów. Referentka podkreśliła, że Simmlowskie pojęcie „formy” wprowadzone zostało do badań autorskich jako narzędzie służące do poszukiwania stałych i ciągłych sposobów odnoszenia się jednostek do siebie, niezależnie od charakteru badanego zjawiska. Przedstawiona analiza opierała się na zapisie rozmów zarejestrowanych za pomocą kamery, prowadzonych jednocześnie z obojgiem małżonków i dotyczących ich komunikacji w małżeństwie. Zgromadzony materiał badawczy poddano szczegółowej transkrypcji, a następnie analizie zawartości - rozkładu tematyki i treści rozmów pod kątem wybranych technik metod jakościowych: analizy konwersacyjnej oraz analizy zachowań niewerbalnych.

Temat postrzegania zmysłowego i jego zmieniającej się roli w społeczeństwie podjęła Magdalena Prokopczuk (Akademia Pedagogiki Specjalnej) w referacie Socjologia zmystów - znaczenie perspektywy Simmla w rozwoju subdyscypliny. W nawiązaniu do socjologii Simmla referentka podjęła próbę zarysu socjologii sensorycznej, zwanej osmosocjologią, systematyzacji dotychczasowych ustaleń poznawczych w tej subdyscyplinie, jak również przedstawienia perspektyw badawczych, metodologicznych i interpretacyjnych, a szczególnie szans na rozwój nauki, jakie niesie za sobą wykorzystanie perspektywy sensorycznej w analizie socjologicznej.

Inicjatywy upamiętniające nieżyjących już badaczy są najlepszą z form pamięci o nich. Dzięki twórczym odwołaniom oni i ich dzieła faktycznie funkcjonują we współczesnej nauce. Konferencje, sympozja czy seminaria poświęcone klasycznemu dorobkowi socjologii pozwalają dostrzec jego bogactwo, a także odkryć nowe, wcześniej niewidoczne koncepty w dziedzinie teorii czy empirii. Ukazują także ciągłość dyscypliny w zakresie analiz fenomenów społecznych. 